\title{
Human Security: China's Discourses and Experience
}

Xiao Ren

Institute of International Studies, Fudan University, Shanghai, China

Submitted: 28 February 2016 | In revised form: 3 July 2016 | Accepted: 2 August 2016 |

Published: 6 September 2016

\begin{abstract}
This article addresses three research questions by elaborating on how the idea of human security is understood or defined by the government and social actors in China; how the distinction between the "protection" aspect and "empowerment" aspect of human security is understood and accepted; and what particular downside risks are perceived as pressing human security issues in China. Amongst these the major ones include air pollution, food security, and cyber security. The study reveals that, whilst as a term "human security" is not frequently used, there have been significant discussions leading to the consideration and implementation of various human security practices in China. The idea of human security has been firmly established and threats to human security detected. For both the government and academic community in China, human security and state security are not necessarily confrontational but can rather be combined, often complimenting each other. Recent developments in China are pointing to a positive direction in terms of human security in the country.
\end{abstract}

Keywords: China; empowerment; human security; practice; protection

\section{Introduction}

Human security, defined as freedom from want, freedom from fear and dignity, by the Commission on Human Security led by Sadako Ogata and Amatya Sen, which the UN General Assembly endorsed by referring to the "right of people to live in freedom and dignity," has also drawn attention in China, where it has helped made progress over the years. Though the very term "human security" has not been widely used in China thus far, a number of similar ideas or practices have been flourishing in China recently. This paper tries to elaborate on China's experience with respect to human security by respectively dealing with three major issues, namely, how the idea of human security is understood or defined by the government and social actors; how the distinction between the "protection" aspect and "empowerment" aspect of human security is understood and accepted; and what particular downside risks are perceived as pressing human security issues in China. The paper concludes with an overall assessment of human security practices in China and the right direction indicated by their examination.

\section{The Understanding of Human Security in China}

\subsection{A New Consensus}

In China, the government is often wary of new academic terms and tends not to use them directly. However, the facts, according to our previous study, have clearly shown China's trajectory of increasingly attaching more importance to "human" (both individual and collective) security. Much more attention has been paid to mitigating threats to human security and a number of measures are being taken in the practice to fulfill this mandate [1]. I would like to emphasize the convergence of the idea of human security and China's practices. My findings have disproved the following statement, i.e., "the very notion of 'human security' has so far not appeared in 
the Chinese language in any possible translation, and the People's Republic of China (PRC) has not even accepted or adopted the concept of 'human security' in either domestic development papers or foreign policy guidelines..." [2]. My examination has suggested otherwise. Though the Chinese government has only used the very term "human security" on a few occasions, China has been engaged in the enterprise for enhancing human security.

China's becoming more open and susceptible to human security has much to do with its experience within the United Nations system. As one of P5 members of the UN Security Council, China has long been supportive of the UN, the most important international organization in the world today, and has played a proactive role in various areas such as peace-building, development, and global governance. Over the years, the UN has encountered a number of criticisms and it is widely believed that reforms are needed, of which China is supportive. Nevertheless, Beijing always supports the UN believing that it plays an irreplaceable role in global governance, and tries to prop up the UN to encourage it to play such a role well [3]. This has been an unchanged priority on China's foreign policy agenda.

China's steady backing has boosted the status of the UN in world affairs, at a time when the world is faced with growing global challenges into the first decades of the $21 \mathrm{st}$ century. Meanwhile, the UN has taken the lead in advocating and/or spreading norms or principles, and this helps affect and shape China's perspective. Usually, UN initiatives or proposals attract China's attention and prompt Beijing to take a close look at them, before taking actions to adapt to the new norms or principles. For example, China was involved in the deliberations and adoption of the UN World Summit Outcome document in 2005. Although it is not the same thing as the "Responsibility to Protect" idea proposed by the International Commission on Intervention and State Sovereignty (ICISS) [4], to some extent the Outcome Document is consistent with this in terms of thinking around protection. The Outcome Document attempts to strike a balance between protecting innocent people around the world from being harmed and avoiding the abuse of external intervention or selfish behavior in the name of protection. For this the outcome document imposes limitations by listing four specific crimes against which the international community should take action to protect people from being jeopardized, i.e. via genocide, war crimes, ethnic cleansing and crimes against humanity. In this way the Outcome Document has become a new international legal document. China was involved in this process and made its own contribution to it. Thus, involvement in global or regional institutions has pushed China to clarify or develop its thinking on human security.

Against the backdrop of the great earthquake and tsunami that devastated Japan's Tohoku region, in June 2011, the Ministerial MDGs Follow-up Meeting was held under the UN framework in Tokyo, Japan. China sent Vice Foreign Minister Cui Tiankai to attend the meeting. In the speech he delivered, Cui, as the representative of the Government of China, stated:
"To discuss the MDGs from the angle of human security offers a thought-provoking perspective. We believe that the MDGs and human security are interrelated and should be mutually reinforcing. The MDGs embody so many aspects of human security, while the realization of MDGs aims at greater well-being and security for more people in the first place".

By pointing to the fact that "the general picture of global security remains disturbing. Civilians in North Africa and the Middle East continue to bear the brunt of turmoil. Innocent women and children are still being displaced or killed in armed conflicts in various parts of the world", Cui stated, "These give rise to the call for a new concept on security (italics added) and an international political order where the United Nations should play a central role. We strongly believe that the purposes and principles of the UN Charter should be upheld, and Security Council resolutions should be implemented in a faithful manner. [...] In a word, if human security in the larger sense of the term is still so much threatened, there is little hope for better individual security" [5].

This is an illuminating example of China clearly and definitively adopting and using both the idea and terminology of human security in the context of a formal UN meeting. Though it was an event on MDGs and not specifically on human security, the term "human security" was explicitly employed to express China's opinion and position.

This discourse was reinforced by further developments. In February 2014, Ms. Fu Ying, Chairwoman of the National People's Congress Foreign Affairs Committee, was invited to and spoke at the Munich Security Conference. She argued that the security for people to survive and develop is fundamental to all forms of security. The core of the Chinese Dream of the revival of the Chinese nation, proposed by President Xi Jinping, is to make the 1.3 billion Chinese people live a better and happier life. In other words, all ordinary people have the right and are entitled to live with dignity in a secure environment. This is the attraction of China's success story to the world, as well as the charm of the Chinese dream [6]. This line of thinking has many elements in common with the widely shared "human security" idea. For instance, both have an emphasis on individuals and their happiness, and this has to be fulfilled together with national development. Ends and means should come along together, and the persistent value should be that people should not be sacrificed for whatever national goals.

The key point here is that China's security concept is undergoing a profound transformation. A new consensus has emerged which assumes security does not equal military security, and security should not only be comprehensive but also people-centered. "National security" now has new connotations.

\subsection{The Third Plenum}

During the landmark Third Plenum which was held in November 2013, a major resolution for the comprehensive deepening of China's reform was deliberated and passed. The long reformist document has sixteen parts and sixty items. As an element in the thirteenth part, on a new social 
governance system, it announced the decision to create a new National Security Commission. The purpose is set to improve the relevant institutions and strategy in order to better safeguard China's national security. According to the explanatory speech Xi Jinping gave, reform and development are conditioned on national security and social stability, without which wider reform and development cannot be further advanced. At present, China is faced with the dual pressure of safeguarding national sovereignty, security, and development interests externally and maintaining political security and social stability internally. All kinds of risks that can or cannot be foreseen are clearly increasing while the country's institutions and mechanisms for security cannot meet the need of maintaining national security well, and thus comes the demand for setting up a powerful and capable platform to coordinate the whole national security work. The responsibilities of the National Security Commission include formulating and implementing national security strategies, advancing the construction of national security rule of law, deciding national security guidelines and policies, and studying and solving major issues in the national security work [7]. Quite understandably, this major decision drew considerable attention from both home and abroad.

In April 2014, the first meeting of the new National Security Commission was held. According to the speech Xi Jinping delivered, the security of people has to be the main objective. It has to be insisted upon that state security should in every sense serve the people and rely on people. The mass foundation of state security has to be laid and consolidated [8]. This means that state security and human security is not confrontational but, rather, that the two can be combined in coexistence.

Internally, China is undergoing a modernization process during which a number of contradictions are growing. At a time of rapid economic and social development, a series of social problems are accumulating which have not been "digested" well. Some Chinese observers have noted that "group incidents" resulting from unbalanced distribution of interests break out often and that they are affecting social stability negatively. Externally, the growth of China sees some powers and neighboring countries hedging against China's interests, and as a result contradictions and frictions in China's neighborhood are increasing. Moreover, these challenges to social stability and security from home and abroad are jointly entwined making them difficult to cope with. In the current era, the concept of national security is enriching in depth and widening in breadth, involving various issues in various areas. They cannot be dealt with only via foreign affairs, national defense, and security departments but, rather, are demanding more agencies, social organizations and even the whole of society to work together [9].

Since the initiative to create China's NSC appears in the "social governance system" part of the November 2013 resolution, its domestic and internal security dimension is self-evident. In the meantime, it is also obvious that the commission's work involves two dimensions, i.e. both external and internal, rather than just one. Thus the notion of "security" that the initiative refers to is of comprehensive nature. It is not difficult to come to this same conclusion simply by thinking of the July 5, 2009 incident in Xinjiang, the riots in Tibet and Tibet-related immolations in its neighboring provinces, and the killing at the Kunming Railway Station on March 1, 2014. During all these incidents innocent people were killed or injured and some of the incidents were taken advantage of by hostile external forces. That is arguably why it is pretty widely believed that internal security will be the dominant concern for China's NSC, at least in its early stage. When ordinary people can be harmed by violent terrorist attacks in any place and without any warning, a sense of insecurity arises and this can be frightening. Thus, when freedom from want is no longer a problem in today's China, it is reasonable to expect that ordinary people may also be free from fear. A broad concept of security of this kind logically becomes the goal for China's NSC.

In fact, as Cui Shunji of Zhejiang University points out, since the initiation of reform, China's high-level attention paid to poverty reduction, the pursuit for a sustainable development model, and China's proposals for constructing a "harmonious society" and "harmonious world" all indicate that China has regarded guaranteeing basic human needs, social justice and harmony, as well as sustainable development as a continuum for national security [10]. "Letting people live a happier life with more dignity" has become the goal of national development, which indicates that China's recognition of human security has been elevated to the political level. Putting people first and "governing for the people" have become the new thinking for governing the country. As a reflection of the foreign policy changes, handling foreign affairs for the country is shifting to handling foreign affairs for the people [10].

\subsection{The "Non-Traditional Security" Discourse}

In China's research community, "human security" is often related to the discourse on "non-traditional security" [11], a term used for years. Obviously, so-called "non-traditional" matters are in stark contrast to more "traditional" matters. Traditional security usually refers to military security, namely, assuring national security through boosting military power. After the end of the Cold War, threats to security increasingly come from non-military domains and become unconventional or "non-traditional" security threats. There are many examples of such issues and they have often been listed as financial crisis, terrorism, transnational crime, environmental degradation, the spread of HIV Aids, scarcity of water resource, food security, and so forth.

According to the summation by a leading Chinese researcher, non-traditional security is broad-based, complex, and multi-dimensional. First, non-traditional security is broad-based: While traditional security falls into military, political, and diplomatic areas, and its supreme value is the pursuit of peace and the elimination of war or the "possibility of war," non-traditional security is more about economic, social, cultural, environmental threats as well as the emerg- 
ing cyber security and space issues. In addition to peace, "non-traditional security" relates to risk, crisis, emergency, and daily threats to life. It also relates to natural disaster accidents, emerging public health incidents, and major public security events.

Second, non-traditional security is complex: Threats to non-traditional security are mainly threats to "societal security" and "human security". Society and its people are the chief referent objects of non-traditional security, and a "safe China" has societal and human dimensions. For individuals, "safety" means that the security of people is guaranteed or, namely, that individuals enjoy a state of existence in which a person's body is not injured, mind not harmed, property not deprived, and living environment not undermined.

Third, non-traditional security is multi-dimensional: According to the place and origin of non-traditional security events, the threats to non-traditional security facing a country can be placed into four categories: (1) "exogenous" non-traditional security threats which take place abroad and chiefly require a diplomatic approach; (2) "endogenous" non-traditional security threats which take place at home and chiefly require domestic handlings; (3) "bi-dogenous" ( 双源性 ) non-traditional security threats which take place in the peripheral areas that involve both domestic and international handlings; and (4) "multi-dogenous" (多源性) non-traditional security threats that involve both traditional and non-traditional security issues and require the involvement of the military in addition to other organizations [12].

Throughout the above process of ideational transition, there occurred a few landmark crises that strike China deeply, including the 1997 Asian financial crisis which highlighted the importance of financial security, the 2003 SARS crisis which highlighted public health security, and the March 1, 2014 terrorist attacks at the railway station of Kunming, capital of Yunnan Province. The March 1 violence against innocent people especially amplified the serious security threat that ordinary people could encounter in their daily lives. This genuine risk gave rise to a widespread sense of fear.

Until recently security policy in China was mainly focused on state security, the importance of which nobody denied. Now, "human" security has been put forward and it is gaining momentum. It has undeniable value orientation. In fact, Chinese scholars speak highly of "human security" and argue that it goes beyond the limits of state-centric traditional security research and is the least traditional theory in the non-traditional security domains [13]. Human security research explicitly sees people as a collectivity and individuals as the referent object of security. This transcends the dilemma of more traditional security theory, since the state can bring about insecurity to its citizens. Such a possibility, after all, raises a question over the relationship between state security and human security. Generally speaking, Chinese researchers do not endorse the view that individual security overrides state security or that the two are confrontational, but rather affirm the reasonableness and value of state security at the same time.
For Shi Bin, a professor at Nanjing University, the human security idea is a focal embodiment of non-traditional security and "new security" concepts, and yet the relationship between "human security" and state security is actually much more complicated. He has tried to elaborate on this in the following ways.

First, both state security and human security, in terms of their security concern or value pursuit, have legitimate claims. However, neither of them can become absolutely dominant. "Human security" is of course the fundamental goal and ultimate value of human development. The value orientation of putting people first with "human security" at the center possesses the moral high ground and legitimacy. However, a person has both individuality and sociality, and an individual is often weak and helpless. Resisting foreign military invasion and safeguarding national sovereignty and territorial integrity are therefore in the nation's common interest. Nonetheless, the traditional state-centric security idea and strategy indeed ignore the security needs of many nonstate or sub-national entities, and cannot adequately deal with external non-military threats such as environmental degradation and pandemic disease.

Second, although there is a tension between "human security" and state security, and the two may conflict in practice, they still can be mutually accommodating and complimentary if handled and balanced well, and therefore be favorable for upgrading the overall security degree of all entities. People's security and welfare, and the improvement of their living condition and life quality, are an important base for national identity, social stability and political legitimacy. In this sense, "human security" and state security are not necessarily contradictory [14]. For Shi, the "human security" discourse has tangible Western value orientation, and in practice has a tendency of overriding the security interests of the sovereign state. The acclaimed "paradigm shift" from the state to individual excessively downgrades the positive role of the state in dealing with various security challenges.

For Zhang Yunling of the Chinese Academy of Social Sciences, the rise of non-traditional security issues does not mean that traditional security is no longer important. The appearance of non-traditional security on the agenda and it being stressed imply that it has been included in the category of "security", and therefore the formation of a "comprehensive security" concept that includes both traditional and non-traditional security as well as the corresponding security policies seems to be desirable [15].

Taken together, when "non-traditional security" is increasingly becoming the mainstream discourse in China, the researchers tend not to deny the value of state security but rather see human and state security as mutually accommodating. Nevertheless, the theoretical shortcoming of "non-traditional security", as Guoguang Wu rightly points out, is obvious as it is generally deployed against "traditional security" without any positive and substantive defining of the contents and nature of new "securities" [2].

Moreover, these days many things are securitized and many issues become security issues. This may not be a 
healthy situation. When security is discussed too much, this could lead to a growth in insecurity. For example, in China, "food safety" was not discussed often before but is now widely talked about. This implies food safety was not an issue but it is now. The deterioration of food safety is a negative development which involves the need for moral reconstruction in society.

Thus interaction between state security and personal security is not a zero-sum game. The more state security does not mean the less personal security, and vice versa. The ultimate goal should be a calibrated balance between the two.

As has been shown, the Chinese research community has attached more importance to the issue of "human security" in recent years. Meanwhile, they are not just following others' footsteps, but have come up with their own analyses and views. Some researchers stress that both the starting point and ultimate purpose of any society is the individual. The emancipation of the individual should be the fundamental core of any social emancipation. It is the individual who is the final destination of security and the core value any security is supposed to protect, while the state is the means or a temporary purpose [16]. The establishment of the idea that "the individual is the purpose" as a value has great significance for the Chinese society, after having drawn lessons from the history of the People's Republic since 1949.

During the Cultural Revolution period, many innocent people were attacked, detained, or persecuted illegally and immorally, and the rights of people ignored or harmed. After that disastrous decade, people reflected on their painful experience and thought about the phenomena of imposing horrible acts on innocent people which should never happen again. In the early reform period, there emerged a movement in China's intellectual community aimed at promoting the discussion of issues around humanism (rendao zhuyi) and alienation (yi hua), during which many academics affirmed the significance of humanism and argued for the promotion of human value. Some of them cautiously adopted the term "Marxist humanism" or "socialist humanism" to distinguish from the so-called "capitalist" doctrine. Not long after, the debate abruptly came to a halt due to a political intervention. However, along with further economic reform and considerable social development, the awareness of the individual man or woman in China was awakening and the value of the individual confirmed. The initiative towards humanism which began in the 1980s in fact became accepted by the whole of Chinese society over time. This was also reflected in discussions and research on "human security" since it was made clear that guaranteeing human security is the value basis for maintaining non-traditional security. The protection of people and human development should be set as the ultimate goals of any security policy. This is a decisive and valuable intellectual progression.

The paradigm of human security opposes harm towards human freedom and rights for motives of economic growth or social stability. Neither is it in favor of pursuing economic benefits and communitarian policies at the expense of sacrificing the security and dignity of the individual or the nation. The fundamental reason lies in the value of the individual which is the key and ultimate aim, and there is no higher goal than this.

The previous practices of both "collective security" and "common security", as one leading scholar in human security-Yu Xiaofeng-argues, could not have avoided the limitations arising when the state is regarded as the chief actor. Aside from these, the notion "shared security," which Yu proposes, regards the human community as the central target and beneficiary of security, the protection of human life as the value base of security, social safety and prosperity as the priority goal of security, and harmony and cooperation as the supreme principle for security interactions between the states [17]. This goes beyond the traditional discourse and has the potential of being further developed theoretically.

\section{Protection and Empowerment}

According to the Human Security Now report and the October 2012 resolution adopted by the United Nations General Assembly as a follow-up to paragraph 143 on human security of the 2005 World Summit Outcome, human security has two dimensions, i.e. protection and empowerment. In China, the dimension of protection has drawn much attention, as is epitomized in the doctrine of "putting people first" (yiren weiben) and "diplomacy serving the people" (waijiao weimin), which we have discussed in detail in an earlier study [1]. This is reinforced by further evidence and here is one example. There was a Chinese newspaper correspondent who reported from the National People's Congress (NPC) sessions and wrote about his experience. He was deeply impressed by the attention the NPC delegates paid to the concrete issues concerning people's daily lives, including social insurance, income distribution, rights of peasant workers, food safety, unreasonably high drug prices, and protection of stakeholders' interests. For him, never before had those kinds of issues been so meticulously discussed at the NPC [18]. The changes the correspondent detected indicated positive ongoing trends in human security terms.

A harmonious society has to be a society that puts people first, which means people's everyday life is a priority for that society. A government that puts people first is a government that represents people's interests. Economic and social development should put human development at the center, and human development is the ultimate value judgment for social progress [18]. Meanwhile, "the achievement of human security is a cooperative venture between individual, society, and the state [19]". Government as a "necessary evil" is very much a Western invention and it is not a Chinese idea. Traditionally, people in China often have strong wishes regarding government and they want government to do good things for them. Compared to the Western political culture, they have less vigilance and more expectations for government. One revealing example is the use of the term "parent officials" (fumu guan) to refer to 
government officials, which indicates that they are expected to play a paternalistic role. Without a cooperative venture, human security cannot be achieved.

On the protection side, while people-oriented ideals are noble ones, the challenges come from the process of implementation. Not surprisingly, many problems are encountered, a prominent one among which involves the area of land recruitment and resident relocation. Sometimes the failure to protect the rights and interests of ordinary people has led to conflict, and in some cases even extreme acts of protest. When property development businessmen and power coalesce, they arguably together undermine the interests of the ordinary people who are affected. Protecting people's legitimate interests has become an outstanding issue in China's human security amidst drastic social changes and urbanization.

Moreover, the leadership came into office with a promise to narrow a widening gap between rich and poor and shift to a more environmentally and economically sustainable growth model. "GDP worship" has prevailed since GDP became the government officials' principle measure of accomplishment, leading to the initiation of "achievement projects" and "image projects". These poorly planned projects can lead to ill-conceived planning and environmental damage. When this became obvious, a shift of policy had to be undertaken. "No GDP growth at the expense of environment" is becoming a new norm and "ecological civilization" the new banner.

The reform era has been characterized by success in terms of rapid economic growth and the improvement of people's living standard. After three decades of successful economic development, the country was standing on a new starting point. If the ruling party's historical promise to 'let some people get rich first and eventually arrive at common prosperity" was a prerequisite for reforms to unfold, and if three decades later this historical task was basically fulfilled, what the reform enterprise has to accomplish now is that promised common prosperity. This is a goal that will justify and inform further reforms. The reaffirmation of realizing common prosperity in line with the principles of governing for the people and building a comprehensive and balanced well-off society will guide future reform with a clear direction [20]. To fulfill its pledge to narrow the gap between rich and poor and "unwaveringly pursue common prosperity", the leadership has to have the people in their heart and take them seriously. This is part of the "Chinese dream" which is not a bad term. What the new leader, Xi Jinping, expressed right after the 18th Party Congress, "To fulfill the people's desire for better lives is what we shall strive for", sounded dear and close to the ordinary Chinese people.

On the empowerment side, there have also been a number of measures. Only when a person has the capability for survival and development can he or she enjoy real freedom. The capacity for development empowers an individual. Today's China should not only accept empowerment besides protection, but also appreciate its importance as a way to realize human freedoms and guarantee human security [21].

Education as a right is the fundamental and most significant form of empowerment, as human experience has repeatedly revealed. Thus, educational development is a significant way to empower people, especially compulsory education. China has reasons to be proud in this regard. It possesses a tradition that puts much emphasis on education, in which parents always try their best to pave the way for their children to receive good education, and often they are willing to make sacrifices. In China, nine-year compulsory education has been in practice for years. In 1989, Project Hope was set up as a supplement which later became well-known throughout Chinese society. It was initiated by the Central Youth League and the China Juvenile Development Foundation as a philanthropic enterprise to help less developed areas to establish primary schools, financially support dropped-out children in poorer regions to return to the school, and improve education in the rural areas. The project received society-wide attention and support. Implemented successfully, the project has positively changed the fate of hundreds of thousands of kids from poor families and also beefed up the whole of society's awareness of educational importance, therefore helping to enhance China's fundamental education.

As a major initiative for the future, the Third Plenum set the aim to modernize China's "governance system" and governing capability, a long-term goal for China. An important part of it is the shaping of a new social governance system. During the 2014 National People's Congress session, President Xi joined the Shanghai delegation for deliberation of the government's work. For him, the key for future social governance is institutional innovation, and its core lies in the people. Only when our people are living harmoniously can society operate stably and in an orderly manner. For Han Zheng, the party secretary of Shanghai, social governance is up to everybody, and the governing process should serve the all-round development of the people. Rule of law is the foundation of social governance, without which there can be no basis for long-standing good governance and robust stability [22]. For that matter, what is required of the grass-root cadres includes regarding people's matters as their own matters, whilst always trying to understand their feelings and demands. Again, the key challenge is to make this happen in real life. Fortunately, in China, there have been local autonomous grassroots organizations that play an intermediate role and serve to help handle problems at a grassroots level. They offer assistance to ordinary people who encounter any difficulty, and they also, for example, mobilize donations to help people in regions that have been stricken by earthquake or by other natural disasters. The work of these local self-help organizations has proved to be useful and reassuring in terms of social governance.

\section{Prominent Human Security Threats and the Chinese Responses}

Since "human security is central to non-traditional security, what it is concerned about are all kinds of factors that are directly threatening human security" [23]. In today's China, prominent among those direct threats are air pollution, food safety, and cyber security. 


\subsection{First, the Air Pollution Threat}

2013 was a year that impressed everybody in China with the seriousness of air pollution. Heavy smog emerged in not just North and Northeast China, but was also reported in other regions, creating an alarming situation. The degree of seriousness caused alarm in neighboring Japan and South Korea as well. As the smog was spread, it became obvious that the environment people were living in was deteriorating. The situation acted as a red light signaling the dangers of the existing pattern of economic growth, which was consuming a great amount of energy and yielding considerable waste. If people had already been aware of the issue, smog's covering the whole country in 2013 shocked and awakened everybody to an unprecedented degree. Different from before, the threat and the related risks became real and present. With many people walking in the streets were wearing masks, the sense of human insecurity became tangible and imminent. In this context, the specific threat of air pollution almost became the number one risk in people's minds, though as will be seen shortly, that has remained as food safety.

To cope with this threat, in June 2013 China's State Council laid out ten measures to prevent and combat air pollution. As a follow-up, in September, China released an Action Plan to implement this, in the form of a blueprint to fight against air pollution by 2017 .

This desire to act has continued. In his Government Work Report delivered in March 2014, Premier Li Keqiang swore to "fight pollution like fighting poverty". When he was looking around the city of Beijing, President Xi emphasized that the sprawling pattern of urban development had to be contained and steps should be taken to deal with smog pollution and improve air quality. Among the five requests Xi made, one was logically to reinforce the degree of reining in air pollution. The top priority set for combating air pollution and improving air quality was to control PM2.5, and major steps should be taken in areas including reducing burn of coal, strictly limiting the growth of car use, adjusting industries, tightening management, and joint prevention and control [24]. Xi's move clearly sent a signal that steadfast measures were needed for better air quality.

Previously, the Chinese leadership pledged to launch a "revolution in energy production and consumption," and said that urbanization must be balanced with "ecological security" [25]. However, pollution was worsening - which is now posing a serious threat to human health and social stability. To reduce air pollution and carbon emissions, Beijing (pop. 20 million) is attempting to phase out coal-fired power plants within the city's urban core, replacing them with cleanerburning natural gas power plants. These measures are also basically valid for other cities. After all, fighting pollution is relevant to everybody's security and this has become a high-degree consensus within Chinese society.

Similarly, China's energy sector had a watershed year in 2013 also. Reforms that could have a profound impact on China's environment and energy policy were floated. And with concerns over air pollution mounting throughout the year, the country is poised to shift away from its reliance on coal and to use more clean energy including natural gas. Shale gas exploration is making progress in parts of the country. Driven by the crises, a true transformation is under way but surely will take time.

\subsection{Second, Food Safety}

In recent years, there have occurred a series of food contamination incidents throughout the country which caused serious concerns among the Chinese people. While the broadcast of the recording movie $A$ Bite of China is absolutely popular nation-wide, a bite of food and its safety has become a case in point. A 2010 poll by Xiaokang ( 小康 Moderately Well Off) Magazine and Tsinghua University in 12 Chinese cities found that food safety ranked number one of all social concerns among those surveyed, reflecting mounting anxiety after the 2008 melamine crisis [26,27].

In the context that the continual food safety problems are plaguing China and threatening human security, it is not true that the government is unaware of or insensitive to the food safety problems. When appearing before the press conference, Premier Le Keqiang responded by stressing that "food safety is of utmost importance" (2013 National People's Congress press conference). When answering the question concerning the missing MH370 aircraft, he stressed that "a case involving human life has to be treated with utmost care" (renming guantian). Again, the 2014 Government Work Report promises to adopt the strictest surveillance, the most severe punishment, and the most serious accountability measures to resolutely govern hygiene on the dinner table and reassure "security on the tongue tip" [28]. In fact, making efforts to ensure food safety is a widely shared necessity and a consensus in China.

Specialists distinguish the issue into two kinds, one is food security which refers to sufficiency in quantity, and the other is food safety which refers to the quality of food. While the former involves whether there is sufficient overall provision of food, for which China avows to "hold the bowl firmly in our own hands," the latter involves whether people can be assured they eat food safely everyday. In the good old way, food scarcity trumpeted food safety. But today the main problem in China lies in food safety as people are alarmed by the risk of different forms of contamination. This even spilled over into China's foreign relations, as was epitomized in the spoiled Jiaozi (Chinese dumpling) incident between China and Japan recently.

The incident originated in Hebei Province. An employee in the Tianyang food factory resented his income. As revenge he deliberately poisoned some Jiaozi. The contaminated Jiaozi were exported to and sold in Japan. Some customers bought and ate them and were contaminated. Eventually, pesticides were found in the frozen dumplings exported from China to Japan. This was a single case of crime that caused grave consequences. The reputation of China's food products was seriously hurt and the Sino- 
Japanese relationship was somewhat affected also. This once again highlighted the close link between domestic and international issues.

In the final analysis, the root cause lies in individuals. The issue of "moral collapse" has been raised to refer to the situation. To what extent it is true can be debated. It was believed that the overuse of fertilizer and pesticide was rampant. Disconcertingly, the growers distinguished between what they themselves ate and what was to be sold in the market, passing on lower quality food for consumption by customers. Again how widespread the phenomenon is can be discussed, yet the existence of these kinds of practice suffices to make people feel unsafe regarding food.

As a result, there has arisen a lack of public trust in food safety. Tighter regulation has to be carried out. More transparency is needed to help build public trust, including more official data and statistics about improvement (or deterioration) in food safety, more freedom for media and civil society to verify official data, more effective actions from the government in handling corruption and misconduct in food safety practices, and more protection for whistle-blowers who uncover the production of unsafe food and, more importantly, the corrupt officials involved. Further measures have to be taken for China's improved food safety regulations, consumer education, as well as supply chain traceability and sustainability.

\subsection{Third, Cyber Security}

The internet use has increasingly become a part of people's everyday life in China. By 2013, there were over 600 million internet users in the country, and mobile internet users reached 461 million. The numbers are increasing and China has the largest number of netizens in the world. Thus cyber security has become a prominent issue. In fact, China is one of the major victims of cyber attacks. The covert activities which Edward Snowden revealed highlighted the vulnerability of those nations and individuals who are monitored illegally and immorally [29].

At the government level, a Central Small Leading Group on Cyber Security was created. It was emphasized that cyber security involved national security and development, as well as the career and everyday life of the vast majority

\section{References and Notes}

[1] Ren X, Yanxing L. A Return to People: China's Approach to Human Security. In: New Approaches to Human Security in the Asia-Pacific. Farnham, UK: Ashgate; 2013.

[2] Guoguang W. Human security challenges with China. In: Guoguang W, editor. China's Challenges to Human Security-Foreign Relations and Global Implications. London, UK: Routledge; 2013. pp. 1-27.

[3] Kim S. In: Economy E, Oksenberg M, editors. China Joins the World: Progress and Prospects. New York, NY, USA: Council on Foreign Relations Press; 1999. pp. 42-89.

[4] The Responsibility of Protect. In: International Commission on Intervention and State Sovereignty. Ottawa, Canada: International Development Research Centre; 2001. of ordinary people, and was therefore a major strategic issue [30]. The breakdown and vulnerability of the internet can have widespread impact on people and their lives and therefore must be avoided.

\section{Conclusion}

This article has addressed its three research questions by elaborating on how the idea of human security is understood or defined by the government and social actors; how the distinction between the "protection" aspect and "empowerment" aspect of human security is understood and accepted; and what particular downside risks are perceived as pressing human security issues in China, the major ones being air pollution, food security, and cyber security.

As has been indicated, though as a term "human security" is not frequently used, there have been significant discussions and various human security practices in China. The idea of human security has been firmly established and threats to human security detected, while problems exist as China has been undergoing a still unfinished process of industrialization, urbanization, and drastic social change. The good news is that progress is being made. And theoretically, only when the security of the individual is of paramount importance in policy making, can there be globally accepted values. China has gotten far beyond the lip service level of cheaply talking about people's interests. They are now integrated into human security in its full sense. Threats to human security can include domestic risks, yet they are often transnational ones such as air pollution and sand-storms. They require different sectors of society and neighboring countries to work together.

Over twenty years ago, the Commission on Global Governance produced a report which emphasized the distinction between the security of states and the security of peoples [31]. Twenty years later, the security of peoples has gained momentum. This is also true in China, the most populous country in the world. China's practices have considerably reinforced the overall trends of affirming the value of people, protecting their lives, whilst pursuing legitimate interests and dignity, and empowering them not only to survive but also to live a respectful life. What is happening in China is indicating a positive trend in this direction.
[5] From commitment to concerted action. Embassy of the People's Republic of China in the Republic of Rwanda. 2011 Jun 2. Available from: http://news.xinhuanet.com/politics/2013-11/15/c_118164294.htm.

[6] Media Library. Munich Security Conference. Available from: https: //www.securityconference.de/en/media-library.

[7] For the full text of the Resolution and Xi's explanation, see Renmin ribao (People's Daily) November 16, 2013. Available from: http://politics.people.com.cn/n/2013/1115/c1001-23559327.html;;

[8] See Renmin ribao (People's Daily), April 16, 2014. p.1.

[9] Hu H, Dong W. Ruhe kandai sheli guojia anquan weiyuanhui (How we should perceive creating the National Security Commission). Liaowang News Weekly. 2013 Nov 18; pp. 30-31.

[10] Cui S. Ren de fazhan yu ren de zunyan: zaisi ren de anquan gainian (Human Development and Human Dignity: Rethinking the 
Concept of Human) Security). Guoji anquan yanjiu (Journal of International Security Studies). 2014;1:63-77. doi:10.14093/j.cnki.cn101132/d.2014.01.004.

[11] Breslin S. Debating Human Security in China: Towards Discursive Power? Journal of Contemporary Asia. 2014;45(2):243-265. doi:10.1080/00472336.2014.907926.

[12] Yu X, editor. Zhongguo feichuantong anquan yanjiu baogao (Report on China's Non-Traditional Security 2012-2013). Beijing, China: Shehui kexue wenxian chubanshe (Social Sciences Academic Press); 2013.

[13] Xiaofeng Y. Gongxiang anquan: fei chuantong anuan yanjiu de zhongguo shiyu (Shared Security: A Chinese Perspective on the Study of Non-Traditional Security). Guoji anquan yanjiu (Journal of International Security Studies). 2014;1:4-34.

[14] Shi B. Ren de anquan yu guojia anquan ('Human Security' and National Security). Shijie jingji yu zhengzhi (World Economics and Politics). 2014;1:85-110.

[15] Zhang Y. In: Preface. Beijing, China: Shehui kexue wenxian chubanshe (Social Sciences Academic Press); 2012. pp. 1-4.

[16] Li J. Ren de anquan: fei chuantong anquan nengli jianshe de xinshijiao (Human security: a new perspective on the non-traditional security capacity building). In: Xiaofeng Y, editor. Zhongguo fei chuantong anquan nengli jianshe (Non-Traditional Security Capacity Building in China). Beijing, China: Zhongguo shehui kexue chubanshe; 2013. pp. 106-121.

[17] Xiaofeng Y. Gongxiang anquan: fei chuantong anuan yanjiu de zhongguo shiyu (Shared Security: A Chinese Perspective on the Study of Non-Traditional Security). Guoji anquan yanjiu (Journal of International Security Studies). 2014;1:4-34.

[18] Yuan X. Ren de daxie (People Amplified). Wenhui Daily. 2005 Mar 8; Available from: http://www.news.cn/.

[19] Bedeski RE. Anthropocentric Theory of Human Security. In: Guoguang W, editor. China's Challenges to Human SecurityForeign Relations and Global Implications. London, UK: Routledge; 2013. pp. 28-53.
[20] Editorial. 21st Century Economic Report (Ershiyi shiji jingji baodao). 2003 Oct 16 ; p. 2.

[21] Kaisheng L, Shanghai Academy of Social Science. Personal communication; 2013 Dec 7.

[22] Bianzhi chengshi guihua yao youwei yeyao wuwei (What to do and not to do in urban planning). Wenhui Daily. 2014 Mar 7; p. 1.

[23] Yu X, editor. Zhongguo fei chuantong anquan yanjiu baogao (Report on China's Non-Traditional Security 2011-2012). Beijing, China: Shehui kexue wenxian chubanshe (Social Sciences Academic Press); 2012. Available from: http://theory.people.com.cn/n/2014/0305/ c49150-2453655.

[24] Xi Jinping puts forward five requests for the City of Beijing. Renmin ribao (People's Daily). 2014 Feb 27; Available from: http: //news.xinhuanet.com/politics/2014-02/26/c_119519301.htm.

[25] FT Special Report "China". Financial Times. 2012 Dec 12; Available from: http://www.ft.com/cms/s/2/46725ce8-3afc-11e2-bb3200144feabdc0.html.

[26] Zhang Z. Food Security Tops People's Concern in Survey. The China Daily. 2010 Jun 30;Available from: www.chinadaily.com.cn/ china/2010-06/30/content_10042303.htm.

[27] Wishnick E. Food security and food safety in China's foreign policy. In: Guoguang W, editor. China's Challenges to Human SecurityForeign Relations and Global Implications. London, UK: Routledge; 2013. pp. 245-260.

[28] Li K. Zhengfu gongzuo baogao (Government Work Report). Renmin ribao (People's Daily). 2014 Mar 14; Available from: http: //theory.people.com.cn/n/2014/0305/c49150-2453655.

[29] Meng W. Wangluo anquan: guojiazhanlue yu guoji zhili (Cyber security: National strategy and international governance). Dangdai shijie (Contemporary World). 2014;2:46-49.

[30] The First Meeting of the Central Small Leading Group on Cyber Security was Held. Renmin ribao (People's Daily). 2014 Feb 28; Available from: http://www.gov.cn/ldhd/2014-02/27/content_2625036.htm.

[31] Our Global Neighborhood. Commission on Global Governance. Oxford, UK: Oxford University Press; 1995. 